\title{
The first record of translocated white-clawed crayfish from the Austropotamobius pallipes complex in Sardinia (Italy)
}

\author{
Julien AMOURET,,${ }^{1,2 *}$ Silvia BERTOCCHI, ${ }^{3}$ Sara BRUSCONI, ${ }^{3}$ Marco FONDI, ${ }^{3}$ Francesca GHERARDI,${ }^{3 \dagger}$ \\ Frédéric GRANDJEAN, ${ }^{2}$ Lorenzo A. CHESSA, ${ }^{4}$ Elena TRICARICO,${ }^{3}$ Catherine SOUTY-GROSSET ${ }^{2}$
}

${ }^{1}$ Department of Life and Environmental Sciences, University of Iceland, Sturlugata 7, 101 Reykjavik, Iceland; ${ }^{2}$ Laboratoire Ecologie \& Biologie des Interactions, Equipe Ecologie Evolution Symbiose, UMR CNRS 7267, Université de Poitiers, 5, rue Albert Turpin, TSA 51106 F-86073 Poitiers Cedex 9, France; ${ }^{3}$ Dipartimento di Biologia, Università di Firenze, Via Romana 17, 50125 Firenze, Italy; ${ }^{4}$ Dipartimento di Protezione delle Piante-Ecologia, Università di Sassari, Via E. De Nicola 9, 07100 Sassari, Italy *Corresponding author: jua6@hi.is

\begin{abstract}
The white-clawed crayfish Austropotamobius pallipes complex is native to Europe, being present in 18 European countries, Italy included. However, the number and abundance of its populations are today restricted and it has been recently classified as endangered by IUCN (International Union for Conservation of Nature). Here, we report the first record of this freshwater crayfish in Sardinia Island (Italy). Using a fragment of the mitochondrial DNA $16 \mathrm{~S}$ rRNA gene, we identified three haplotypes that correspond to the A. italicus meridionalis subclade. We provide information about the sampling area, population density and finally discuss hypotheses about the occurrence of this population in Sardinia, comparing it with other Mediterranean populations. Our results improve the existing knowledge about the phylogeography of the taxon across Italy, confirming its complex pattern of distribution. In addition to the non-native status of the Sardinian A. i. meridionalis crayfish, we showed that the most proximal Mediterranean population of white-clawed crayfish existing in Corsica belongs to A. pallipes from Southern France.
\end{abstract}

Key words: Austropotamobius pallipes species complex, DNA barcoding, endangered species, Sardinia, Corsica.

Received: November 2014. Accepted: March 2015.

\section{INTRODUCTION}

The white-clawed crayfish Austropotamobius pallipes (Lereboullet, 1858) has a wide geographic range in Europe, from Scotland in the North to Spain in the South and from the European Atlantic front in the West to the Montenegro in the East (Souty-Grosset et al., 2006; Holdich et al., 2009). Populations of this species have been recorded in 18 European countries, but those from Austria, England, Ireland, Portugal, Eastern Spain and Wales, as well as from Corsica, Liechtenstein and Scotland, appear to have originated from human introductions (Grandjean et al., 2001; Gouin et al., 2003; Souty-Grosset et al., 2006; Holdich et al., 2009). Since the 1860 s, the number of $A$. pallipes populations has been sharply decreased due to the combined effects of several drivers of environmental change; i.e., habitat loss and degradation, water pollution, overfishing or competition from non-indigenous crayfish species. The European native crayfish $A$. pallipes is also facing the spread of the crayfish plague, a lethal disease caused by the oomycete Aphanomyces astaci (Schikora, 1903) (Souty-Grosset et al., 2006). As a result of its rarefaction, even leading to the extinction of the species in Portugal (Holdich et al., 2009), A. pallipes is included in Annexes II and V of the European Union Habitats Directive
(92/43/EEC) as a species requiring special conservation measures. It has also been recently promoted by the International Union for Conservation of Nature (IUCN) from the status of vulnerable (Baillie et al., 1996) to the status of endangered (Füreder et al., 2010).

For a decade, many attempts have been made to conserve and restore A. pallipes populations (Souty-Grosset et al., 2003, 2006; Souty-Grosset and Reynolds, 2009). However most of these actions suffered from the absence of a well-defined taxonomy (Fratini et al., 2005; Manganelli et al., 2006). Indeed, the species shows a large genetic heterogeneity that might have originated from the climate changes occurring in Pleistocene and its confinement in glacial refugia (Santucci et al., 1997; Pedraza-Lara et al., 2010). Numerous taxonomic revisions have been done over the last five decades (Bott, 1950; Karaman, 1962; Starobogatov, 1995). As well as the taxonomical status of the A. pallipes species remains as unsolved and uncertain, some genetic studies based on sequences of the 16S rRNA and CO1 mitochondrial genes (Grandjean et al., 2000, 2002; Matallanas et al., 2011), partially supported by morphological (Bott, 1950; Karaman, 1962; Brodski, 1983; Grandjean et al., 1998; Bertocchi et al., 2008a) and allozyme data (Santucci et al., 1997), suggest the existence of two different lineages (Grandjean et al., 
2000; but see Chiesa et al., 2011; Scalici and Bravi, 2012). The first is $A$. pallipes, distributed across most river basins from France, the Rhine and Rhône drainages of Switzerland, the North-western Italy, the South-western tip of Germany and the British Isles (Grandjean et al., 2002; Zaccara et al., 2004; Souty-Grosset et al., 2006; Stefani et al., 2011). The second species is A. italicus (Faxon, 1914), present in Italy, Dalmatia and the Iberian Peninsula (Grandjean et al., 2000; Fratini et al., 2005; Souty-Grosset et al., 2006). The latter was further distinguished into four subspecies with a well-defined geographic distribution, i.e., A. i. italicus (Faxon, 1914), mainly found in the Central Apennines in Italy, two localities in the South of France and in Spain, A. i. carsicus (Karaman, 1962), distributed across the Dinaric and Eastern Alps, A. i. carinthiacus (Albrecht, 1981), found in Central and North-Western Italy, Austria and Switzerland, and A. i. meridionalis occurring in Southern Italy and Slovenia (Fratini et al., 2005). However, A. italicus has not yet been officially recognized as a separate species (Grandjean et al., 2000), and the systematics of $A$. pallipes is still under debate (Trontelj et al., 2005). Several authors have thus decided to adopt the cautious approach of retaining A. pallipes as a species complex (Souty-Grosset et al., 2006; Reynolds and Souty-Grosset, 2012). The present study acknowledges the existence of a species complex comprising A. pallipes and four subclades of A. italicus.

The taxonomic status of the crayfish populations inhabiting the Italian islands is still unknown. In continental Italy, the species occupies three different climatic areas, with altitudes comprised between 90 and $1050 \mathrm{~m}$ asl, from coastal areas on the Mediterranean Sea to the Alps and the Apennines (Holdich et al., 2009). Aquiloni et al. (2010) argued that its current distribution is the result of two distinct factors; the first is the competition with the river crab, Potamon fluviatile (Herbst, 1785) (Barbaresi and Gherardi, 1997; Gherardi and Cioni, 2004), and which may have started in the Pleistocene when the two species met after their migration from Eastern Europe (Pretzmann, 1987). The second factor is the frequent release by humans of crayfish into the wild. Populations of the A. i. meridionalis subclade, for example, occur in Tuscany, where instead $A$. i. italicus is to be expected (Fratini et al., 2005). Indeed, voluntary introduction of crayfish associated with their use as a food delicacy is a common practice in Western Europe, as abundantly documented in the literature (Grandjean et al., 1997, 2000, 2001, 2002; Largiadèr et al., 2000; Gouin et al., 2003; Machino et al., 2004). Here, we report the first finding of the species on Italian islands, i.e., Sardinia; this new population was then genetically compared with other Italian and European populations to find possible relationships by using the mt DNA $16 \mathrm{~S}$ rRNA. Moreover, we added some new genetic data of the Corsican white-clawed crayfish as the most proximal population to the Sardinian one, to elaborate the most parsimonious scenario explaining its origin in Sardinia.

\section{METHODS}

\section{Study area}

The sampling took place at the stream called Basile, part of the Coghinas hydrographic basin in Sardinia Island, Italy (about $50 \mathrm{~km}$ from Sassari; 40 23'21.1'N, 8०54'17.9'E; altitude: $575 \mathrm{~m}$ asl). Isolated from inhabited areas, it is classified as salmonid water by the local Fish and Wildlife Offices (T: $15^{\circ} \mathrm{C}$; oxygen: $8.9 \mathrm{mg} / \mathrm{L}$; conductivity: $190 \mu \mathrm{S} / \mathrm{cm} ; \mathrm{pH}: 7.87)$. The stream bottom is covered by cobble, stones and boulders that, together with the abundant tree roots, are known to provide shelter to crayfish (Naura and Robinson, 1998). The area is part of a Site of Community Interest (SCI) under the Habitats Directive (Catena del Marghine Goceano). Due to the altitude range determining a wide climatic and phytoclimatic diversification, 750-800 species, comprising 38 endemisms and many plant species of phytogeographic relevance, occur, along with nine natural habitat types of community interest (three of which of priority relevance) and 28 threatened species of vertebrates (three mammals, 15 birds, six reptiles and four amphibians). Freshwater animal species of conservation concern include Emys orbicularis (Linnaeus, 1758), Salmo cettii (Rafinesque 1810), and Euproctus platycephalus (Gravenhorst, 1829).

\section{Population density}

In June and August 2010, after a preliminary inspection of the site, crayfish that at first glance were assigned to the A. pallipes complex were collected by hand by three persons walking upstream for 90 min during the night. This in-depth survey was conducted by turning rocks and investigating among roots and detritus. Immediately upon capture, sex was noted and the cephalothorax length (CL), including rostrum, was measured using a Vernier caliper. The occurrence of scars, mutilations, and visible ectosymbionts (e.g., Branchiobdellidans) was recorded. After measurements, crayfish were released at the collection site.

We computed the catch per unit effort (CPUE, the number of crayfish divided by the time spent for sampling; individuals $\mathrm{min}^{-1}$; Demers and Reynolds, 2002; Scalici and Gibertini, 2005) and density (individuals $\mathrm{m}^{-2}$ ).

\section{Genetic analysis}

A piece of claw was taken from each collected individual, preserved and stored in $95^{\circ}$ ethanol for this study and for future genetic analyses. This does not cause any damage to the animal because appendages regenerate after successive moults. The DNA was extracted following a standard 
Phenol-Chloroform extraction protocol. The amplification of a fragment of the mitochondrial DNA 16S rRNA gene (412 bp) was performed by PCR using two primers: $16 \mathrm{~S}$ ar (5' - CGCCTGTTTAACAAAGACAT - 3') and 16 S-br (5' - CGGTCTGAACTCAGATCACGT - 3') (Palumbi et al., 1991).

The following PCR conditions were applied: 40 cycles for $1 \mathrm{~min}$ at $95^{\circ} \mathrm{C}$ for denaturation, $1 \mathrm{~min}$ at $50^{\circ} \mathrm{C}$ for annealing, $1 \mathrm{~min}$ at $72^{\circ} \mathrm{C}$ for extension, preceded by $5 \mathrm{~min}$ of initial denaturation at $93^{\circ} \mathrm{C}$ and followed by $5 \mathrm{~min}$ of final extension at $72^{\circ} \mathrm{C}$. PCR products were visualized in $1.5 \%$ agarose gels (1\% TBE) stained with SYBR-Safe (Lonza, Belgium). The DNA size marker used was the Smart ladder Eurogentec ${ }^{\circledR}$ (200 to 10,000 pb). Successful double-strand PCR products were purified with the ExoSAP-IT buffer (USB, Cleveland, OH, USA) and then sequenced using the Big Dye v. 3.1 Terminator Kit on a capillary automated sequencer ABI PRISM 3130 (PE Applied Biosystem, Carlsbad, CA, USA). For most samples, the forward and reverse sequences were obtained. In addition to the Sardinian individuals, we sequenced some specimens from Corsica and France; all the haplotypes are available in GenBank under the accession numbers KP866104-KP866115. Sequences from Grandjean et al. (2000), Largiadèr et al. (2000), Zaccara et al. (2004), Fratini et al. (2005) and Pedraza-Lara et al. (2010) were added to the sample dataset to increase the accuracy of the analysis.

\section{Phylogenetic inference}

We restricted the location selection to Italy and Southern France. Sequences from A. torrentium from Switzerland were added as an outgroup to the overall dataset. First, we used a Bayesian inference implemented in BEAST 1.8.0 (Drummond et al., 2012) for computing the species phylogeny and detecting the taxonomical affiliation of the Sardinian population. We selected the HKY (Hasegawa et al., 1985) substitution model in MEGA 6 (Tamura et al., 2013) with selection on the lowest Akaike Index Criterion (AIC). Three Metropolis-coupled Markov chains (MCMC) were run 10 million generations with trees sampled every 1,000 generations. We used TRACER 1.6 (http://beast.bio.ed.ac.uk/Tracer) to check that all Effective Sample Size (ESS) were largely exceeding the minimum value of 100 to ensure the meaningful estimation of parameters. The different runs were combined using LogCombiner 1.8.0. (http://beast.bio.ed. ac.uk/logcombiner). We discarded the first $10 \%$ trees in TreeAnnotator 1.8 (http://beast.bio.ed.ac.uk/treeannotator). Then, we visualized the trees topologies in FigTree 1.4.2 (http://tree.bio.ed.ac.uk/software/figtree/). Secondly we added to the posterior probabilities of the Bayesian inference, the bootstrap values from a Maximum Likelihood analysis (1000 repetitions, MEGA 6; Tamura et al.,
2013), to support the main branches of the species complex phylogeny.

\section{Phylogeographic origin}

F-statistic $\left(\Phi_{\text {ST }}\right)$ and its probability values (P-values) were computed in Arlequin 3.1 (Excoffier et al., 2005), with 1000 permutations, for each geographic unit of the subspecies A. i. meridionalis; e.g., Po basin including several populations [Prato (5), Bormida (10), Vignole A. (10) and Visone (10)], Southern Italy [Crati (8), Sele (15) and Umbria (18)], and Sardinia (Fig. 1). We reported the same divergence indices between the Corsican population and the A. pallipes populations from France and Northern Italy (Po River).

\section{RESULTS}

\section{Morphological description}

We checked all the diagnostic characters for A. pallipes as reported by Holdich et al. (2006). One individual is shown in Fig. 2. Colour is brown to olive with pitted appearance; the maximum total length recorded was $7 \mathrm{~cm}$. The carapace was smooth with a pitted appearance with a single pair of post-orbital ridge on it. A row of tubercles was found on the shoulder of the carapace behind the cervical groove. The ends of pleura from the second to the fourth abdominal somites were rounded without sub-terminal spines. The areola between branchiocardiac grooves was evident. The rostrum was broad-based, with smooth borders converging to a long sharp acumen; a simple median carina runs down its length; the dorsal surface was covered in mat of fine setae. The topside of the chelae was weakly granular and the underside was dirty-white colour. Two widely spaced tubercles were present on the inner side of the fixed finger with obvious incision between them; no prominent spur was found on the inner margin of the cheliped carpus.

\section{Population description}

We recorded 188 crayfish (95 males and 93 females) and the sex ratio did not significantly differ from 1:1. CPUE and density were of 2.08 ind. $\mathrm{m}^{-1}$ and 2.03 ind. $\mathrm{m}^{-2}$ respectively. Overall, $12 \%$ crayfishes were found without a cheliped and $17.7 \%$ had a regenerated one. No scars or ectosymbionts were found and no individual showed apparent symptoms of either thelohania or aphanomycosis.

\section{Phylogenetic inference}

The data matrix of 223 mitochondrial DNA 16S rRNA gene sequences of Austropotamobius spp., consisted of eight samples from Sardinia, 19 from Corsica, nine from the Rhône (France) and six samples from the French Eastern Pyrénées, were supplemented by 181 sequences re- 
trieved from GenBank (Tab. 1). The topology of the Bayesian phylogenetic tree (Fig. 3) allowed us to affiliate the Sardinian samples as a population of $A$. i. meridionalis. Moreover, we noticed that the added samples from Corsica belonged to the $A$. pallipes clade.

\section{Phylogeographic origin}

Within A. i. meridionalis, we found no genetic differentiation between Sardinian population and South Italian populations [Crati (8), Sele (15 and Umbria (18)] (Tab.1) nevertheless, the pairwise $\Phi_{\text {st }}$ values between the Sardinian population and the A. $i$. meridionalis from the Po River (Bormida [10], Vignole A. [10] and Visone [10], Tab. 1) showed a significant genetic differentiation: $\Phi_{\text {st }}=0.280, \mathrm{P}<0.05$. We also noticed a slight differentiation between the Sardinian and the Southern Pyrenean sample but in a lower order of magnitude: $\Phi_{\text {st }}=0.109, \mathrm{P}=0.06$. The pairwise $\Phi_{\text {st }}$ value between the Po River and Southern Italy was slightly the same between Sardinia and the Po River: $\Phi_{\text {st }}=0.306, \mathrm{P}<0.05$.

The Corsican population displayed larger significant divergence with the other population of $A$. pallipes of the present study (vs Rhône; $\Phi_{\mathrm{st}}=0.482, \mathrm{P}<0.001$ and $v s$ the Po River; $\left.\Phi_{\text {st }}=0.310, \mathrm{P}<0.001\right)$. However, both Tyrrhenian populations were highly significantly differentiated $\left(\Phi_{\mathrm{st}}=0.951, \mathrm{P}<0.001\right)$.

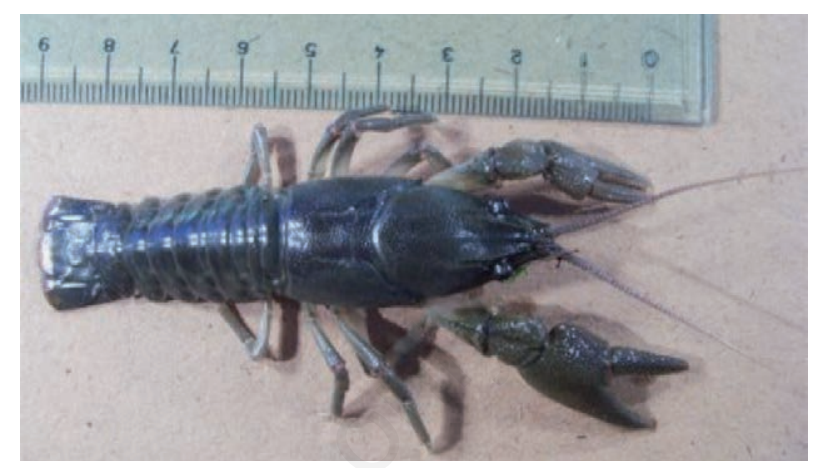

Fig. 2. An individual of Austropotamobius italicus meridionalis from the study site in Sardinia.

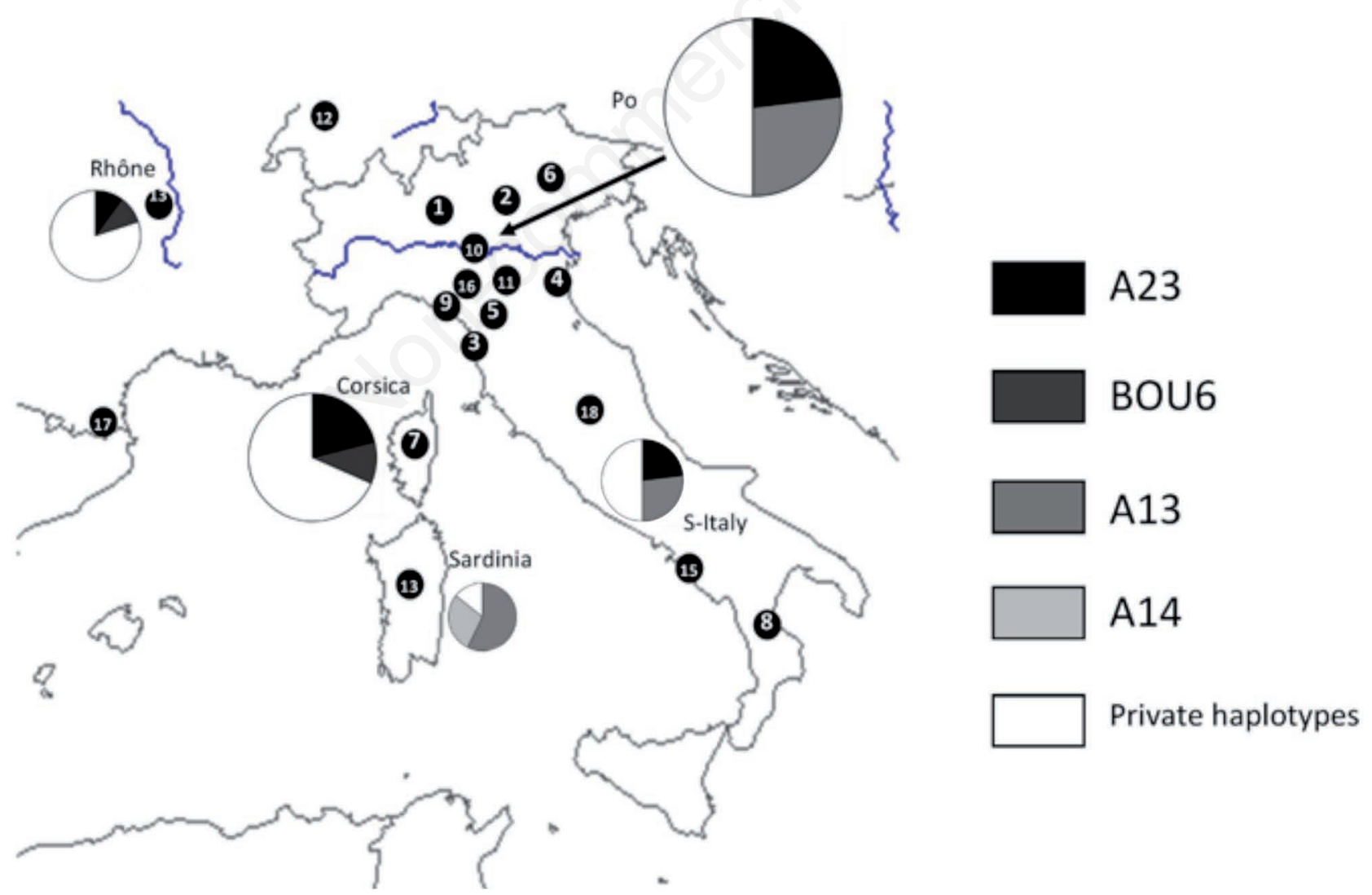

Fig. 1. Locations of the different populations of Austropotamobius sp. Haplotypes restricted to one sampling location (i.e., private haplotypes) are represented in white within pie charts while haplotypes shared between locations are shaded using a grey scale. The size of pie charts is proportional to the sampling size. 


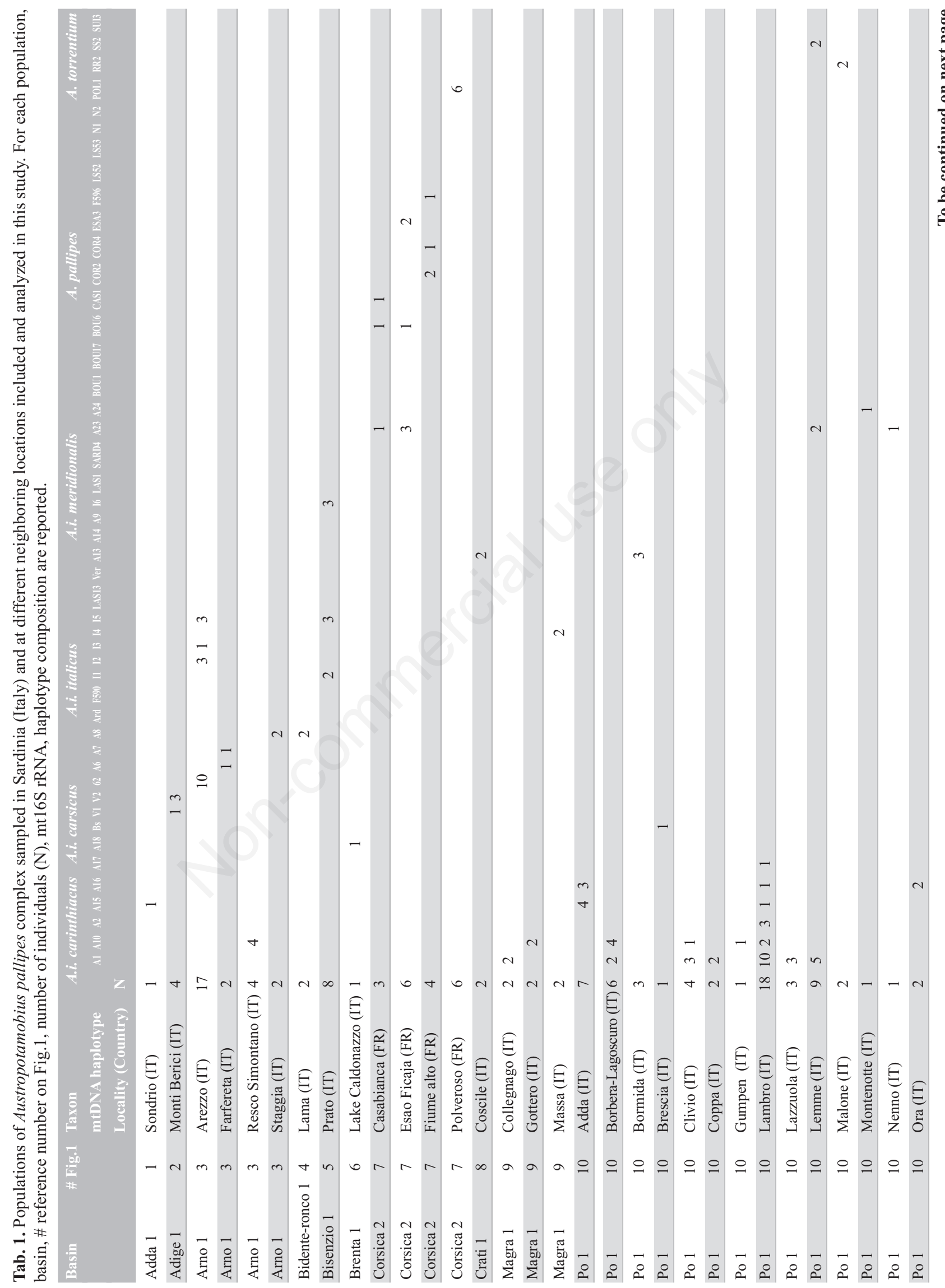




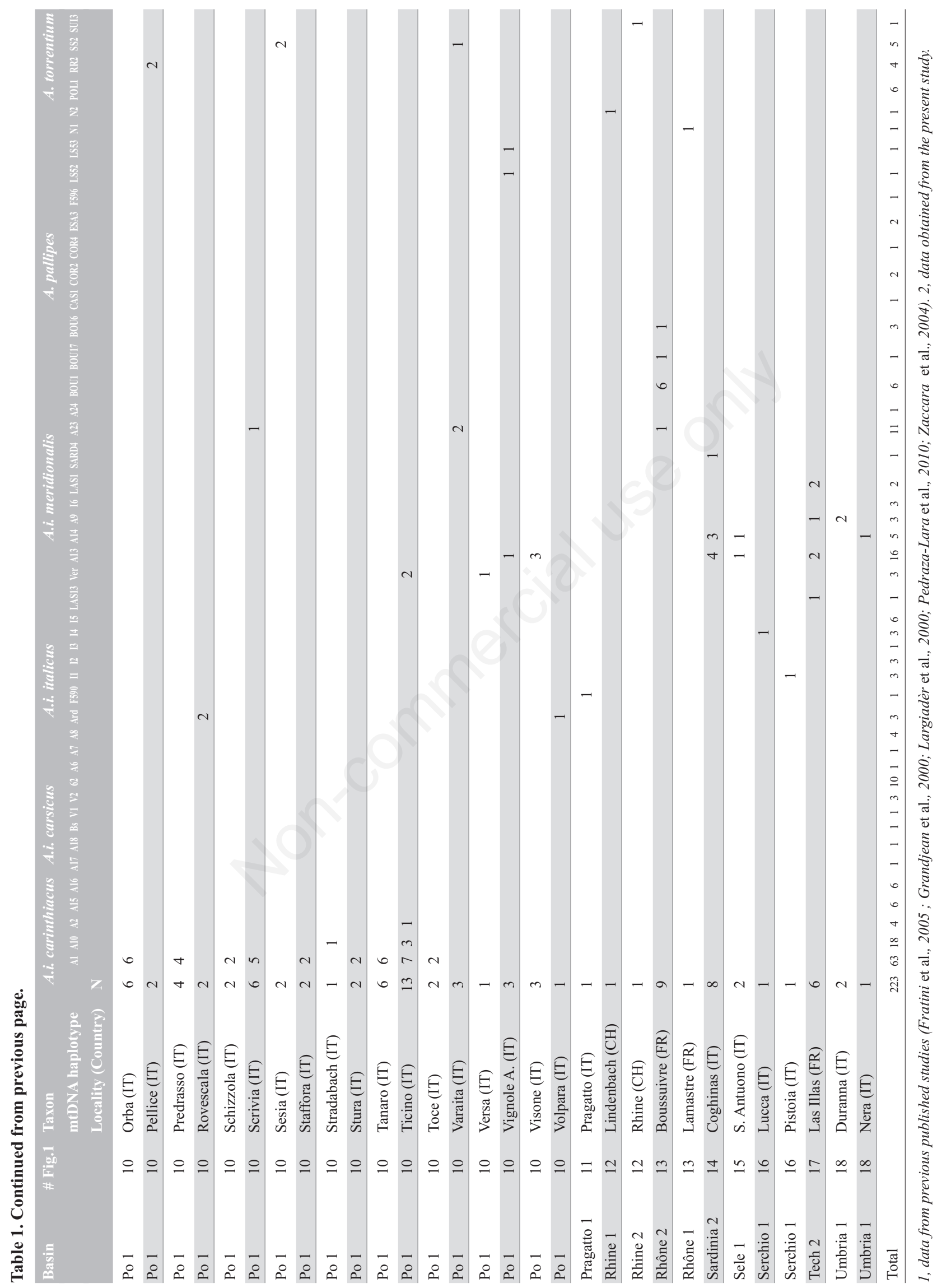




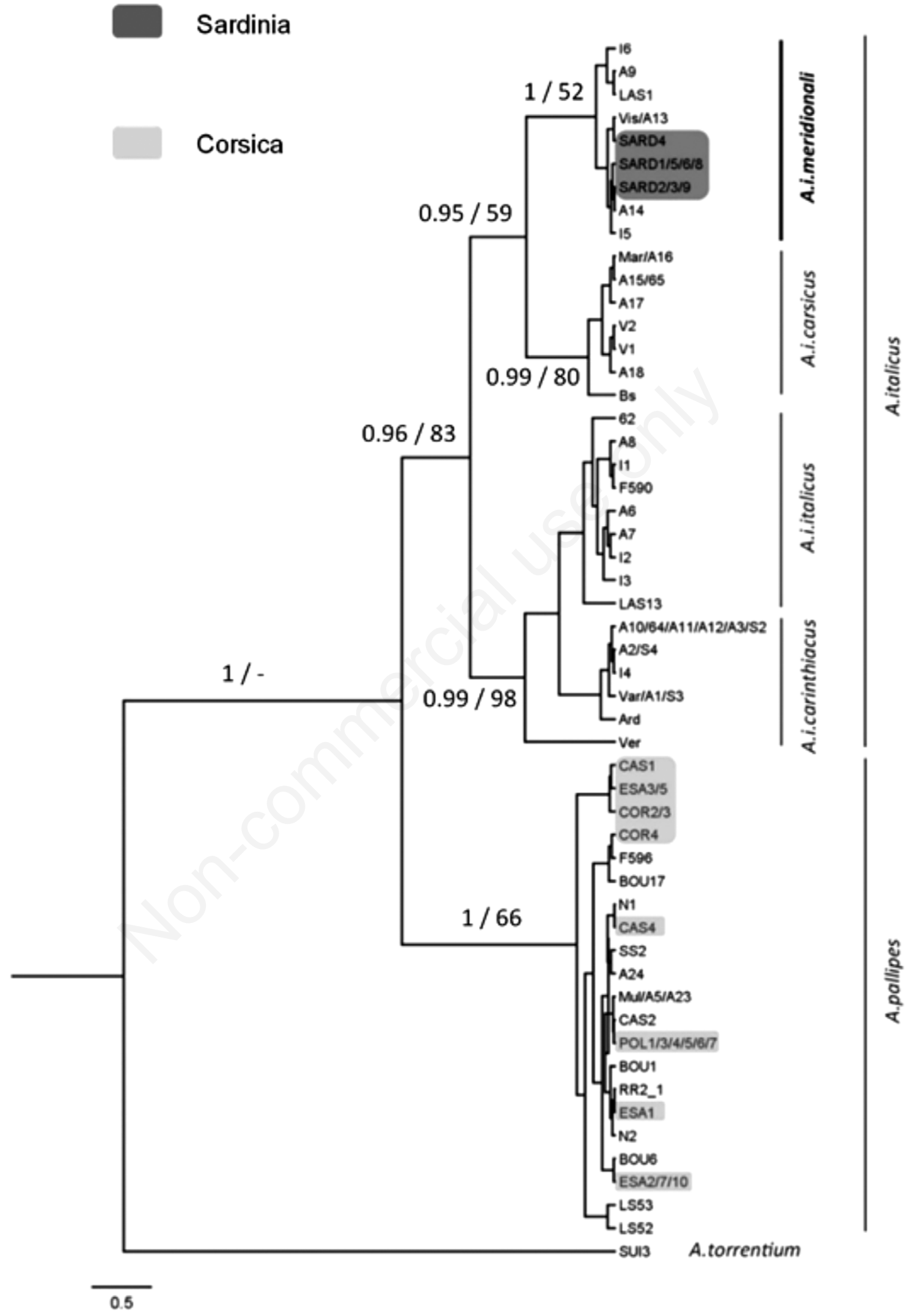

Fig. 3. Bayesian consensus tree based on mtDNA 16S rRNA haplotypes. Numbers above branches are the Bayesian posterior probabilities and the bootstrap values from Maximum Likelihood inference respectively. 


\section{DISCUSSION}

Considering the decline reported for A. pallipes complex in other Italian regions and European countries (Füreder et al., 2003; Lyons and Kelly-Quinn, 2003; Scalici and Gibertini, 2005), the study population seems to be healthy, similarly to some populations sampled in Tuscany, Central Italy (Brusconi et al., 2008). It shows indeed high CPUE values (0.93 maximum in Scalici and Gibertini, 2005; 2.12 maximum in Brusconi et al., 2008), a balanced sex-ratio, a relatively low number of injured individuals, and no scars, ectosymbionts or signs of diseases. Our phylogenetic analysis reveals that the Sardinian population of crayfishes under study belongs to the A. i. meridionalis subclade, which thus extends its distribution from France, Spain, Slovenia and continental Italy to the Sardinia Island.

If this Sardinian population might result from a natural genetic divergence, both the Pleistocene climate and the regional geomorphological history might have influenced the splitting of species. As shown in Proseallus species (Matthaeis et al., 2001), the natural genetic divergence of the Sardinian population is the largest within its Mediterranean distribution. This is not the case in our dataset; the Sardinian population is genetically very similar to the Southern Italian populations of $A$. i. meridionalis. However, given that the separation of the Corsica-Sardinia microplate ranged between 50-25 million years before present (MYBP) and 16-12 MYBP (Alvarez, 1972), the genetic pool of any endemic population in Sardinia would have been much more differentiated from the other Italian and European populations. This hypothetically isolated relic population would have shown a unique genetic pool characterised by a much more stronger genetic divergence than we have found in this study. Consequently, a recent human-mediated translocation seems to be the most probable explanation of our findings because of the close similarity of the Sardinian genetically type with other Southern Italian populations of A. i. meridionalis; i.e., we found low and non-significant F-statistics values with the populations from Sele, Crati and Umbria. Recent studies revealed that translocation events are numerous as discovered both in Maritim alps (Stefani et al., 2011) and the record of a population of the southern lineage of A. italicus; i.e., a non-native taxon, in northern Alps (Chucholl et al., 2015). Thus, notwithstanding the abundant literature on A. pallipes complex, a better knowledge of its distribution is needed. The boundaries of its native distribution are difficult to trace due to the spreading of crayfish by humans through voluntary introductions and the construction of new canals. Even if A. pallipes complex is non-indigenous in Sardinia, it deserves a permit of residence (Böhme, 2000), and should be protected from the several threats acting in the area, such as the progressive habitat degradation and loss, the increased human fishing and the spread of North American crayfish species vector of the crayfish plague (Procambarus clarkii is already present in the adjacent Province of Olbia-Tempio; Holdich et al., 2009; Piscia et al., 2011). Genetic analyses, combined with ethological, ecological, and demographic studies (Brusconi et al., 2008; Bertocchi et al., 2008b), will help undertake the appropriate conservation actions.

\section{CONCLUSIONS}

The population of Austropotamobius pallipes complex in Sardinia belongs to the A. i. meridionalis subclade and, according to our findings, it seems to be healthy. Due to its permit of residence, as recommended by Cataudella et al. (2010) we encourage the protection and conservation of the local habitat of the nominate specimen to face any habitat degradation, increased human fishing as the spread of the North American crayfish, Procambarus clarkii.

\section{ACKNOWLEDGEMENTS}

We thank the Corpo Forestale dello Stato of the Station of Bono and Bachisio Virdis for his precious collaboration in collecting data. We thank Mr. Mario Deroma (Department of Agriculture of the University of Sassari) for the cartography. We are really thankful for the suggestions made by two anonymous reviewers.

\section{REFERENCES}

Alvarez W, 1972. Rotation of the Corsica-Sardinia microplate. Nature 235:103-105.

Aquiloni L, Tricarico E, Gherardi F, 2010. Crayfish in Italy: distribution, threats and management. Int. Aquat. Res. 2:1-14.

Baillie J, Groombridge B, Barden A, Cox N, Gray B, Stuart S, Sneary M, Johnson T, Reay J, 1996. 1996 IUCN red list of threatened animals. IUCN, Gland: 448 pp.

Barbaresi S, Gherardi F, 1997. Italian freshwater decapods: exclusion between the crayfish Austropotamobius pallipes (Faxon) and the crab Potamon fluviatile (Herbst). Bull. Fr. Pêche Piscic. 347:731-747.

Bertocchi S, Brusconi S, Gherardi F, Buccianti A, Scalici M, 2008a. Morphometrical characterization of the Austropotamobius pallipes species complex. J. Nat. Hist. 42:2063-2077.

Bertocchi S, Brusconi S, Gherardi F, Grandjean F, Souty-Grosset C, 2008b. Genetic variability of the threatened crayfish Austropotamobius italicus in Tuscany (Italy): implications for its management. Fund. Appl. Limnol. 173:153-164.

Böhme W, 2000. When does a foreign species deserve a "permit of residence"? Non-indigenous species (NIS): examples of varying exoticness and varying immigration age, taken from herpetology. Ethol. Ecol. Evol. 12:326-328.

Bott R, 1950. [Die Flusskrebse Europas (Decapoda, Astacidae)].[Book in German]. Kramer: 36 pp.

Brodski SY, 1983. On the systematics of palaearctic crayfishes (Crustacea, Astacidae). Freshwater Crayfish 5:464-470.

Brusconi S, Bertocchi S, Renai B, Scalici M, Souty-Grosset C, Gherardi F, 2008. Conserving indigenous crayfish: stock assessment and habitat requirements in the threatened Austropotamobius italicus. Aquat. Conserv. 18:1227-1239. 
Cataudella R, Paolucci M, Delaunay C, Ropiquet A, Hassanin A, Balsamo M, Grandjean F, 2010. Genetic variability of Austropotamobius italicus in the Marches region: implications for conservation. Aquat. Conserv. 20:261-268.

Chiesa S, Scalici M, Negrini R, Gibertini G, Nonnis Marzano F, 2011. Fine-scale genetic structure, phylogeny and systematics of threatened crayfish species complex. Mol. Phylogenet. Evol. 61:1-11.

Chucholl C, Mrugala A, Petrusek A, 2015. First record of an introduced population of the southern lineage of white-clawed crayfish (Austropotamobius italicus) north of the alps. Knowl. Managt. Aquat. Ecosyst. 406:10.

Demers A, Reynolds J, 2002. A survey of the white-clawed crayfish, Austropotamobius pallipes (Lerebouillet), and of water quality in two catchments of the Eastern Ireland. Bull. Fr. Pêche Piscic. 367:729-740.

Excoffier L, Laval G, Schneider S, 2005. Arlequin (version 3.0): an integrated software package for population genetics data analysis. Evol. Bioinform. 1:47-50.

Fratini S, Zaccara S, Barbaresi S, Grandjean F, Souty-Grosset C, Crosa G, Gherardi F, 2004. Phylogeography of the threatened crayfish (genus Austropotamobius) in Italy: implications for its taxonomy and conservation. Heredity 94:108-118.

Füreder L, Oberkofler B, Hanel R, Leiter J, Thaler B, 2003. The freshwater crayfish Austropotamobius pallipes in South Tyrol: heritage species and bioindicator. Bull. Fr. Pêche Piscic. 370-371:79-95.

Füreder L, Gherardi F, Holdich D, Reynolds J, Sibley P, SoutyGrosset C, 2010. Austropotamobius pallipes. In: IUCN 2010 Red List of Threatened Species. Available from: http:// www.iucnredlist.org/details/2430/0

Gherardi F, Cioni A, 2004. Agonism and interference competition in freshwater decapods. Behaviour 141:1297-1324.

Gouin N, Grandjean F, Pain S, Souty-Grosset C, Reynolds J, 2003. Origin and colonization history of the white-clawed crayfish, Austropotamobius pallipes, in Ireland. Heredity 91:70-77.

Grandjean F, Souty-Grosset C, Holdich DM, 1997. Mitochondrial DNA variation in four British populations of the whiteclawed crayfish, Austropotamobius pallipes: implications for management. Aquat. Living Resour. 10:121-126.

Grandjean F, Gouin N, Frelon M, Souty-Grosset C, 1998. Genetic and morphological systematic studies on the crayfish Austropotamobius pallipes (Decapoda: Astacidae). J. Crust. Biol. 18:549-555.

Grandjean F, Harris DJ, Souty-Grosset C, Crandall KA, 2000. Systematics of the European endangered crayfish species Austropotamobius pallipes (Decapoda: Astacidae). J. Crust. Biol. 20:522-529.

Grandjean F, Gouin N, Souty-Grosset C, Diéguez-Uribeondo J, 2001. Drastic bottlenecks in the endangered crayfish species Austropotamobius pallipes in Spain and implications for its colonization history. Heredity 86:431-438.

Grandjean F, Frelon-Raimond M, Souty-Grosset C, 2002. Compilation of molecular data for the phylogeny of the genus Austropotamobius: one species or several? Bull. Fr. Pêche Piscic. 367:671-680.

Hasegawa M, Kishino H, Yano T, 1985. Dating of human-ape splitting by a molecular clock of mitochondrial DNA. J. Mol. Evol. 22:160-174.
Holdich DM, Haffner P, Noël P, 2006. Species files, pp. 50-129. In: C. Souty-Grosset, D. Holdich, P. Noël, J. Reynolds and P. Haffner P (eds.), Atlas of crayfish in Europe. Muséum National d'Histoire Naturelle, Paris.

Holdich D, Reynolds J, Souty-Grosset C, Sibley P, 2009. A review of the ever increasing threat to European crayfish from non-indigenous crayfish species. Knowl. Manag. Aquat. Ecosyst. 11:1-46.

Karaman MS, 1962. [Ein Beitrag zur Systematik der Astacidae (Decapoda)].[Article in German]. Crustaceana 3:173-191.

Largiadèr C, Herger F, Lörtscher M, Scholl A, 2000. Assessment of natural and artificial propagation of the white-clawed crayfish (Austropotamobius pallipes species complex) in the Alpine region with nuclear and mitochondrial markers. Mol. Ecol. 9:25-37.

Lyons R, Kelly-Quinn M, 2003. An investigation into the disappearance of Austropotamobius pallipes (Lereboullet) populations in the headwaters of the Nore River, Ireland and the correlation to water quality. Bull. Fr. Pêche Piscic. 370371:139-150.

Machino Y, Füreder L, Laurent PJ, Petutschnig J, 2004. Introduction of the white-clawed crayfish Austropotamobius pallipes in Europe. Ber. Naturwiss.-Med. Ver. Innsbruck 91:187-212.

Manganelli G, Favilli L, Fiorentino V, 2006. Taxonomy and nomenclature of Italian white-clawed crayfish. Crustaceana 79:633-640.

Matallanas B, Ochando MD, Vivero A, Beroiz B, Alonso F, Callejas C, 2011. Mitochondrial DNA variability in Spanish populations of A. italicus inferred from the analysis of a COI region. Knowl. Managt. Aquat. Ecosyst. 401:30.

Matthaeis D, 2001. A systematic and biogeographical study of epi-and hypogean populations of the Proasellus species group from Sardinia, central Italy and Jordan: allozyme insights. J. Zoo. Syst. Evol. Res. 39:53-61.

Naura M, Robinson M, 1998. Principles of using River Habitat Survey to predict the distribution of aquatic species: an example applied to the native white-clawed crayfish Austropotamobius pallipes. Aquat. Conserv. 8:515-527.

Palumbi SR, Martin A, Romano S, McMillan WO, Stice L, Grabowski G, 1991. The simple fool's guide to PCR. University of Hawaii, Honolulu, USA.

Pedraza-Lara C, Alda F, Carranza S, Doadrio I, 2010. Mitochondrial DNA structure of the Iberian populations of the whiteclawed crayfish, Austropotamobius italicus italicus (Faxon, 1914). Mol. Phylogenet. Evol. 57:327-342.

Piscia R, Volta P, Boggero A, Manca M, 2011. The invasion of Lake Orta (Italy) by the red swamp crayfish Procambarus clarkii (Girard, 1852): a new threat to an unstable environment. Aquat. Inv. 6:45-48.

Pretzmann G, 1987. A contribution to a historic analysis of Mediterranean freshwater decapods chorology. Invest. Pesq. 51:7-25.

Reynolds J, Souty-Grosset C, 2012. Management of freshwater biodiversity: crayfish as bioindicators. Cambridge University Press: 384 pp.

Santucci F, Iaconelli M, Andreani P, Cianchi R, Nascetti G, Bullini L, 1997. Allozyme diversity of european freshwater crayfish of the genius Austropotamobius. Bull. Fr. Pêche Piscic. 347:663-676. 
Scalici M, Gibertini G, 2005. Can Austropotamobius italicus meridionalis be used as a monitoring instrument in Central Italy? Preliminary observations. Bull. Fr. Pêche Piscic. 376377:613-625.

Scalici M, Bravi R, 2012. Solving alpha-diversity by morphological markers contributes to arranging the systematic status of a crayfish species complex (Crustacea, Decapoda). J. Zoo. Syst. Evol. Res. 50:89-98.

Souty-Grosset C, Grandjean F, Gouin N, 2003. Keynote involvement of genetics in knowledge, stock management and conservation of Austropotamobius pallipes in Europe. Bull. Fr. Pêche Piscic. 370-371:165-179.

Souty-Grosset C, Holdich D, Noël P, Reynolds J, Haffner P, 2006. Atlas of crayfish in Europe. Coll. Patrimoine Naturel. Publ. Sci. Muséum National d'Histoire Naturelle, Paris: 187 pp.

Souty-Grosset C, Reynolds J, 2009. Current ideas on methodological approaches in European crayfish conservation and restocking procedures. Knowl. Manag. Aquat. Ecosyst. 394395:01.

Souty-Grosset C, Carral J, Edsman L, Füreder L, Gherardi F, Grandjean F, Haffner P, Holdich D, Madec J, Mannonen A, Noël P, Reynolds J, Schulz R, Smietana P, Taugbøl T, 2006. Conservation of European crayfish, a challenge involving everybody, from the citizen to stakeholders, scientists and decision makers, pp. 160-162. In: C. Souty-Grosset, D. Holdich, P. Noël, J. Reynolds and P. Haffner P (eds.), Atlas of crayfish in Europe. Muséum National d'Histoire Naturelle, Paris.

Starobogatov Ya I, 1995. Taxonomy and geographical distribution of crayfishes of Asia and East Europe (Crustacea Decapoda Astacoidei). Arthropoda Sel. 4:3-25.

Stefani F, Zaccara S, Giovanni B, Delmastro GB, Buscarino M, 2011. The endangered white-clawed crayfish Austropotamobius pallipes (Decapoda Astacidae) east and west of the Maritim Alps, a result of human translocation? Conserv. Genet. 12:51-60.

Tamura K, Stecher G, Peterson D, Filipski A, Kumar S, 2013. MEGA6: molecular evolutionary genetics analysis. Ver. 6.0. Mol. Biol. Evol. 30:2725-2729.

Trontelj P, Machino Y, Sket B, 2005. Phylogenetic and phylogeographic relationships in the crayfish genus Austropotamobius inferred from mitochondrial COI gene sequences. Mol. Phylogenet. Evol. 34: 212-226.

Zaccara S, Stefani F, Galli P, Nardi P, Crosa G, 2004. Taxonomic implications in conservation management of white-clawed crayfish (Austropotamobius pallipes) (Decapoda, Astacidae) in Northern Italy. Biol. Conserv. 120:1-10. 